\title{
KNOWLEDGE ATTITUDE \& BEHAVIOR OF CHERAT COAL MINE WORKERS REGARDING OCCUPATIONAL HEALTH \& SAFETY MEASURES IN NOWSHERA
}

\section{MUHAMMAD ISHTIAQ ${ }^{1}$, RAB NAWAZ ${ }^{1}$, NOOR JAHAN ${ }^{1}$, GHULAM SARWAR KHAN ${ }^{2}$, BUSHRA IFTIKHAR ${ }^{3}$}

1. Department of Community Medicine Pak International Medical College Peshawar,

2. Swabi University

3. Khyber Medical College Peshawar,

\section{ABSTRACT}

Background: Globally, mining is considered as one of the most hazardous occupation. Significant numbers of workers are killed or become disabled due to occupational injuries and diseases. Accidents and injuries occur because of unsafe behavior, poor and specific work knowledge and human errors. A cross-sectional study of consecutive (non probability) sampling technique was carried out from October 2012 to April 2013 in which 252 coal mine workers of Shakot were assessed for Knowledge Attitude \& Behavior safety of occupational health \& safety measures in the Department of Community Medicine Khyber Medical College, Peshawar. The majority of the miners were unaware of the occupational safety at coal mines. $54.76 \%$ had poor, $30.16 \%$, had average knowledge while only $15.08 \%$ had good knowledge of occupational health \& safety measures among coal miners. $43.65 \%$ coal mine workers has low safety attitude and $38.49 \%$ coal mine workers has un-safe behavior of occupational health \& safety measures in coal mines.

Keywords: Coal mining, Knowledge, Attitude, Behavior Safety, Occupational health \& safety

\section{INTRODUCTION}

Mining in general and coal mining in particular is considered as one of the most hazardous occupations worldwide. Many workers are killed or injured due to mining accidents every year throughout the world. Mining, especially underground coal mining due to its peculiar environment poses many occupational hazards to workers. The situation in developing countries like ours remains unchanged. Different occupations have specific inherited hazards; the most important categories include physical, chemical, biological \& psycho-social hazards ${ }^{1}$.

Coal mining is among one of the oldest industry in Pakistan $^{2}$. Coal is the major source of energy being consumed in domestic and commercial sectors including power plants, railway, cement and fertilizers in Pakistan. In Pakistan, there are around 185 billion tons of coal reserves, out of which Khyber Pakhtunkhwa Province contributes about 90 million tons; i.e. from Hangu/Orakzai and Cherat/Nowshera ${ }^{3}$. Despite the fact that all workers are aware of the risk, efforts must be and are being made to increase the safety of mines. ${ }^{4}$
Heavy physical work, severity of the working conditions, work place injuries and often combined occupational dust exposure, are the main causes of occupational morbidity and mortality ${ }^{5,6}$. Only about $7.8 \%$ workers are aware of health hazards and this data is in agreement with other surveys conducted by International Labor organization in Pakistan ${ }^{7}$. Workers were exposed to a variety of occupational hazards and compliance of protective measures were inadequate and poor ${ }^{8}$. The accidents occur mainly because of the management negligence ${ }^{9}$. Studies concluded that personal protective equipments, medical health care services, screening programs will be effective for providing general information on work-related injuries and illnesses ${ }^{10}$. Safety regulations can reduce the frequency of disastrous accidents, but have not reduced mortality rate, which represents overall safety performance ${ }^{11}$. A Korean study concluded that about $62 \%$ of coal miners having knowledge about personnel protective equipments and about $81 \%$ have positive attitude towards respiratory problems associated with coal mining ${ }^{12}$. The incidence of injuries and illnesses is probably very high in 
Pakistan $^{13}$. Training positively affects worker practices $^{14}$. The objective of the study is to assess Knowledge Attitude \& practices Of Occupational health \& safety measures in Shakot/ Cherat Coal Miners, Nowshera, Khyber PukhtunKhwa.

\section{MATERIALS AND METHODS}

A cross-sectional study was conducted from October 2012 to April 2013 at Community Medicine Department, Khyber Medical College; Peshawar. 252 coal miners working in coal mines for at least six months were assessed. All the coal mine workers were carefully scrutinized for their past records if need to be excluded and interviewed on pre designed questionnaire in a friendly environment and local language. Data was analyzed using SPSS. Mean + SD was calculated for numerical variables like age, knowledge. Frequencies and percentages were calculated for categorical variables like knowledge (Good, Average, Poor); attitude (Low, Middle, Positive) and Behavior (Safe, Unsafe).

\begin{tabular}{|l|c|c|}
\hline Demographics & n & \%age \\
\hline Age Distribution & & \\
\hline$<20$ years & 10 & 4 \\
\hline 20-25 years & 106 & 42 \\
\hline $26-30$ years & 45 & 18 \\
\hline $31-35$ years & 28 & 11 \\
\hline 36-40 years and above & 63 & 25 \\
\hline Total & $\mathbf{2 5 2}$ & $\mathbf{1 0 0}$ \\
\hline
\end{tabular}

Age distribution among 252 coal mine workers is given in the table; 1 . Mean age was 30 years with standard deviation \pm 1.26 .

Figure 1. level of knowledge of coal mine workers

Level of Knowledge of Coal Mine Workers

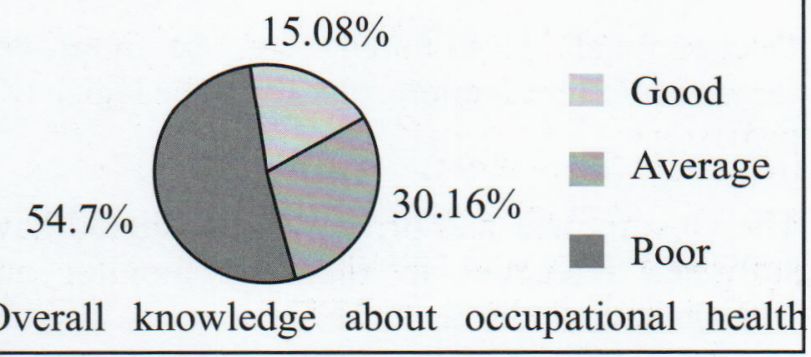

safety measures was analyzed as $54.76 \% n=138$ workers had poor knowledge, $30.16 \% \quad n=76$ workers had average knowledge and $15.08 \% \mathrm{n}=38$ workers had good knowledge. (Fig No. 1).

Figure 2. safety attitude of coal mine workers

Safety Attitude of Coal Mine Workers

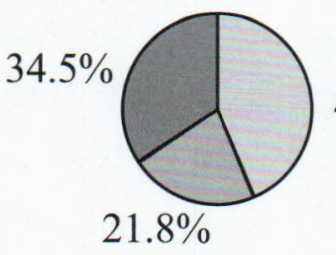

Low

$43.65 \%$ Middle

Positive

Overall safety attitude about occupational health safety measures was analyzed as $43.65 \%$ (110) workers had low safety attitude, $21.83 \%$ (55) workers had middle while $34.52 \%$ (87) workers had positive safety attitude. (Fig No 2).

Safety Behavior of Coal Mine Workers

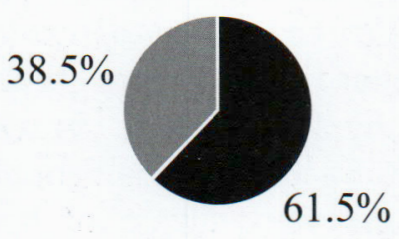

Safe

Unsafe
Overall safety behavior about occupational health safety measures was analyzed as $61.51 \%$ (155) workers had safe behavior, while $38.49 \%$ (97) workers had unsafe behavior. (Fig No 3).

\section{DISCUSSION}

According to an international labor organization (ILO) report the fatality rate at small mines in underdeveloped countries is up to 90 times higher than in industrialized countries. ${ }^{15}$ No occupational 
health and safety (OHS) measures are available in Pakistan $^{15}$.

Majority of these workers were employees at private small scale mines where compliance regarding occupational health and safety (OHS) measures are not followed and this may be one of the reasons for such a high frequency of accidents ${ }^{16}$. In china, for example it is estimated that more than 6,000 fatalities occurs each year in small scale coal mines. Many of these mines are uncertified and having abysmal safety records, these mines are most at risk but cannot be abandoned as $50 \%$ of china's output is provided by such mines ${ }^{17}$.

Another interesting finding in our study is that workers working in coal mines are using primitive methods of mining. This fact has been high lighten in others reports ${ }^{18}$ indicating poor physical and technical standards and use of equipment considered absolute by modern standards, leading to accidents and low production rates ${ }^{19}$.

Our study shows that $55.32 \%$ workers had poor knowledge, $29.92 \%$ workers had average knowledge and $14.76 \%$ workers had good knowledge of occupational health hazards.

The knowledge of the coal mine workers about their occupational health hazards as assessed in this study is poor. Similar findings were observed in another study done by Tariq $\mathrm{A}$ et $\mathrm{al}^{20}$ in which $60 \%$ workers had bad knowledge of health hazards while only $8 \%$ workers were aware of health hazards. It is in agreement with other surveys conducted by International Labor Organization in Pakistan.

Most of the workers $88 \%$ in our study are illiterate and do not know what protective measures should be adopted for their jobs this fact has been explained in different national and international reviews as well ${ }^{21}$. In a report by Ashraf $\mathrm{S}$ et $\mathrm{al}^{22}$, $20 \%$ of the labor force consists of children between the ages of 10 and 18 years in Baluchistan coal mines. Our study also showed induction of children as mine workers in a young age, mean age of staring work at 20 years. Our study supports the findings of others studies ${ }^{15,21}$.

\section{CONCLUSIONS}

The majority of the coal miners are unaware of the occupational health \& safety measures.

They have positive attitude regarding prevention from coal mining hazards but due to various factors they did not follow the protective measures to avoid the coal mine hazards and their associated consequences.

It was concluded that it is of highest importance to educate coal mine workers regarding the fact that $54.76 \%$ have poor level of knowledge about Occupational Health \& Safety Measures.

Despite government concern with occupational health and safety (OHS) and the promulgation of new laws and regulations, a lack of rigor and lax implementation are major impediments to improvements in workplace safety ${ }^{12}$.

\section{RECOMMENDATIONS}

There is immediate need to increase awareness among workers and their operations about the health hazards of coal mining through arrangements of special seminars and training sessions.

There should be regular and periodic medical checkup of coal miners.

The government and private sector should arrange training programs and workshops to educate and train coal mine workers.

Availability of personnel protective equipments will be ensured.

Occupational environment can be improved through efficient implementation of the legislative provisions.

The Government and private sector should have sufficient resources to regularly monitor and inspect the coal mines. 
Legislation should be done to enforce the standards of occupational health \& safety measures in coal mines.

Similar type of research studies be carried out in the country to have basic data for future reference.

\section{REFERENCES}

1. Appalachian Center, SOCM, OVEC, Sierra Club, Coal River Mountain Watch. Toxic Selenium: How Mountaintop Removal Coal Mining Threatens People and Streams. 2009.p.12-23

2. Donoghue AM. Occupational health hazards in mining: an overview. Occup Med (London). 2004 Aug; 54(5):283-9.

3. Alam S.M. The coal \& marble as natural minerals, 2010.

4. Block FW, Thurston H, Dang B. Disposal of Excess Spoil from Coal Mining and the Surface Mining Control and Reclamation Act of 1977. Washington, DC. National Academy Press. 1981.p.28-9.

5. David R. Faces of Coal. The Federation for American Coal, Energy and Security. 2009.p.65-78.

6. Fawell J, Lund U, Mintz B. Coal Mines. BMJ 2002;2:23-45.

7. Finkleman R, Orem W, Castranova V, Tatu C, Belkin H. Health impacts of coal and coal use: possible solutions. International Journal of Coal Geology, 2002;50:425-3.

8. King PM, Fisher JC, Garg A. Evaluation of the impact of employee ergonomics training in industry. Appl Ergon. 1997;28(4):249-56

9. Coleman PJ, Kerkering JC. Measuring mining safety with injury statistics: lost workdays as indicators of risk. J Safety Res. 2007; 38:523-33.

10. Stojadinović S, Svrkota I, Petrović D, Denić M, Pantović R, Milić V. Mining injuries in Serbian underground coal mines-A 10-year study. J. Injury. 2011 Sep; 14:1010-16.

11. Boschetto P, Quintavalle S. Chronic obstructive pulmonary disease (COPD) and occupational exposures J Occup Med Toxicol. 2006; 1:11.

12. Song Q, Tse LA, Yu IT, Wong TW, Griffiths S. Occupational health and safety challenges in China-focusing on township-village enterprises. Arch Environ Occup Health. 2011;66(1):3-11.

13. Vivek V. Khanzode, J. Maiti, P.K. Ray, Occupational injury and accident research: BMJ. 2012;5:1355-67

14. Margolis KA. Underground Coal Mining Injury: A Look at How Age and Experience Relate to Days Lost from Work Following an Injury. Safety Sci. 2010;48(4):41721

15. Yu HM, Ren XW, Chen Q, Zhao JY, Zhu TJ, Guo ZX. Quality of life of coal dust workers without pneumoconiosis in mainland China. J Occup Health. 2008;50(6):505-11.

16. Ashraf S, Zaman M, Ashraf A. Knowledge, attitude, perception of coal mine workers of Shangla district regarding occupational safety measures, Pak J Chest Med 2005;11(1):11-7.

17. Jarup L. Hazards of heavy metal contamination. British Medical Bulletin 2001;68-9.

18. Jennings SR, Blicker PS. Acid Mine Drainage Effects on Fish and Health Ecology: A Review". Reclamation Research Group Publication, Bozeman MT. Kitts, Gene. Why surface mine. 2004.p. 1-5.

19. Lemly A. Aquatic hazard of selenium pollution from mountaintop removal coal mining. Informally published manuscript, Biology, Wake-Forest Univeristy, WinstonSalem, North Carolina.2008.p.23-67.

20. Norton S, Griffith M, Alexander L, Pollard A. Environmental Protection Agency, Office of Research and Development. The effects of mountain top mines and valley fills on aquatic environmental ecosystems of the central appalachian coalfields Washington, DC: Public Health Service, Federal Security Agency and the Federal Works Agency. 2002.

21. Ward Ken. EPA Closing on Spruce Mine Veto. Charleston Gazette. 2010,5:23-45.

\section{For Correspondence: \\ Dr. Muhammad Ishtiaq}

Assistant Propessor,

Department of Community Medicine,

Pak International Medical College Peshawar, 